\title{
FINANCIAL INSTRUMENTS ON COMPANY VALUE IN COMPANIES LISTED IN JAKARTA ISLAMIC INDEX (JII)
}

\author{
by \\ Solichah $^{1}$, Dwi Dewianawati ${ }^{2}$, Erry Setiawan ${ }^{3}$, Agus Sunaryo ${ }^{4}$ \\ ${ }^{1,2,3,4}$ Faculty of Economy and Management Mayjen Sungkono University, Mojokerto, Indonesia \\ Email: ${ }^{1}$ sholihah88@ gmail.com, ${ }^{2}$ dwidewianawati@gmail.com, ${ }^{3}$ erry944@ gmail.com, \\ ${ }^{4}$ sunaryoagus9999@gmail.com
}

\begin{abstract}
Article Info
Article history:

Received July 9, 2021

Revised August 20, 2021

Accepted Sept 11, 2021

Keywords:

Instrument, Financial, Value,

Company

ABSTRACT

Based on the background and problem formulation, the objective is to test, analyze and prove that asset structure, capital structure, macroeconomic, financial risk management, and profitability performance affect the firm value of companies listed in JII. Researchers determine the type of quantitative research. Descriptive data analysis technique, is a technique used to analyze data by describing or describing the data that has been collected. The data used by researchers is secondary data, the data in this study were obtained from the IDX website (Indonesian Stock Exchange). So the population used in this study found 16 companies. Jakarta Islamic Index. The results of the study 1) there is no influence of asset structure on financial risk management, 2) there is an influence of asset structure on profitability performance, 3 ) there is an influence of asset structure on the value of the firm, 4) there is an influence of capital structure on financial risk management, 5) there is the effect of capital structure on profitability performance, 6) there is no effect of capital structure on the value of the firm, 7) there is a macroeconomic influence on financial risk management, 8) there is a macroeconomic effect on profitability performance, 9) there is a macroeconomic influence on the value of the firm, 10) there is the influence of financial risk management on the profitability performance, 11) there is the influence of financial risk management on the value of the firm, 12) there is the influence of profitability performance on the value of the firm.
\end{abstract}

This is an open access article under the CC BY-SA license.

Corresponding Author:

Solichah

Faculty of Economy and Management Mayjen Sungkono University, Mojokerto

Email: sholihah88@gmail.com,

\section{INTRODUCTION}

The development of the Indonesian sharia capital market began with the issuance of sharia mutual funds in 1997 and was followed by the issuance of the Jakarta Islamic Index (JII) in 2000 and the issuance of sharia mudharabah bonds. However, the development of the Islamic capital market until 2017 has not reached a sufficient portion in the capital market industry. The value of sharia shares outstanding is each below $5 \%$ compared to the total shares (sharia and conventional) in circulation, As in table 1.1 (stock development) quantitatively, the number of sharia shares is still small compared to conventional, Until 2018 in August, it was 2,063,421.17 (Rp billion) (source: shari'ah capital market statistics, 2018)

The Sharia Capital Market in Indonesia began with the issuance of Sharia Mutual Funds by PT. Danareksa Investment Management on July 3, 1997, and published the Jakarta Islamic Index (JII) on July 3, 2000 which aims to guide investors who want to invest their funds in sharia. With the presence of the index, investors have been provided with shares that can be used as a means of investing in accordance with sharia principles. On April 18, 2001, for the first time the National Sharia Council of the Indonesian Ulema Council (DSN-MUI) issued a fatwa directly related to the capital market, namely Fatwa Number 20/DSN-MUI/IV/2001 concerning Guidelines for Implementing Investments for Sharia Mutual Funds. , Sharia investment instruments in the capital market continue to grow with the presence of Sharia Bonds. This instrument is the first Syari'ah Bond and the contract used is the mudharabah contract. 
The reason researchers focus on Islamic stocks is because: 1) the economic crisis in 1997/1998 that Islamic banking does not need to be recap by the government. With these achievements, the government believes that Islamic financial institutions can be relied on, as part of the economic system. 2) kompas.com, 30/10/2017, the main director of the IDX said that Indonesia's advantage is that its population is predominantly Muslim (IDX data) familiar with sharia products.

Tabel 1. Stock Index Growth Growth LQ-45, Growth, Jakarta Islamic Index, Growth.

\begin{tabular}{|l|l|l|l|l|}
\hline Years & LQ-45 & Growth & JII & Growth \\
\hline 2013 & 711,14 & - & 585,11 & - \\
\hline 2014 & 898,58 & 187,44 & 691,04 & 105,93 \\
\hline 2015 & 792,03 & 106,55 & 603,35 & 87,69 \\
\hline 2016 & 884,62 & 92,59 & 694,13 & 90,78 \\
\hline 2017 & $1.079,39$ & 194,77 & 759.07 & 64,94 \\
\hline
\end{tabular}

Source : OJK statistic capital market 2018

\section{Formulation of the problem}

Based on the background that has been described, the problem can be formulated as follows:

1. Does the Asset Structure affect the financial risk management of companies listed in JII?

2. Does Asset Structure affect Profitability Performance in companies listed in JII?

3. Does the Asset Structure affect the Value Of The Firm in companies listed in JII?

4. Does the Capital Structure affect Financial Risk Management in companies listed in JII?

5. Does the Capital Structure affect the profitability of companies listed in JII?

6. Does the Capital Structure affect the Value Of The Firm in companies listed in JII?

7. Does Macroeconomics affect Financial Risk Management in companies listed in JII?

8. Does Macroeconomics affect the profitability of companies listed in JII?

9. Does Macroeconomics affect the Value Of The Firm in companies listed in JII?

10. Does Financial Risk Management affect the Profitability Performance of companies listed in JII?

11. Does Financial Risk Management affect the Value Of The Firm in companies listed in JII?

12. Does Profitability Performance affect the Value Of The Firm in companies listed in JII?

\section{Literature Review}

Asset Structure

Weston and Brigham $(2005 ; 175)$ asset structure is a balance or comparison between fixed assets and total assets. Meanwhile, according to Syamsudin (2007: 9) asset structure is the determination of how much funds are allocated for each asset component, both in current assets and in fixed assets.

According to Zaki Baridwan (2004;21), the accounts included in current assets or current assets are 1) Cash available for current business and elements that can be equated with cash, such as checks, money orders, postal money orders. 2) Marketable securities which are short-term investments, 3) Trade receivables and notes receivable, 4) Employee receivables, 5) Installment receivables and installment notes receivable, 6) Merchandise inventory, raw materials, work in process, finished goods, auxiliary materials and materials and spare parts used in the maintenance of tools/machinery, 7) Prepaid expenses such as insurance, rental interest, taxes, petrification materials etc.

apital Structure

Capital structure is a financial measure between short-term debt, long-term debt and own capital in carrying out company activities. Capital structure can be an important problem for companies because good or bad capital structure will directly affect the company's financial position. In the theory of capital structure, it is stated whether or not changes in capital structure have an effect on firm value, with the assumption that decisions and dividend policies do not change.

\section{Capital Structure Theory:}

1. Traditional approach theory;

The traditional approach argues for an optimal capital structure. This means that the capital structure has an influence on the value of the company, where the capital structure can change in order to obtain optimal company value.

2. Approach theory Modigliani and Miller

Modigliani and Miller's theory (MM theory) is a theory that has the view that capital structure is irrelevant and has no effect on firm value. MM theory without taxes; The first modern theory of capital structure is the theory of Modigliani and Miller. They argue that capital structure is irrelevant or does not affect firm value. MM put forward several assumptions to build their theory Brigham and Huston (2005: 31) namely there is no agemcy cost, no tax, investors can borrow at the same interest rate as the company, investors have the same information as management about the 
International Journal of Social Science (IJSS)

Vol.1 No.3 October 2021, pp: 265-274

ISSN: 2798-3463 (Printed) | 2798-4079 (Online)

company's prospects in the future. There are no bankruptcy costs, EBIT is not affected by the use of debt, investors are price takers, in the event of bankruptcy, assets can be sold at market value.

3. Trade-off Theory

According to Brigham and Huston (2005:34) the trade-off theory of leverage provides a statement that companies balance the benefits of funding with debt (favorable personal tax treatment of interest rates and bankruptcy costs with a high fact that interest is a burden that can be reduced by making debt is cheaper than common stock or preferred stock. It can be called debt provides the use of tax protection. So the use of debt will increase the portion of the company's operating profit (EBIT) flowing to investors.

4. Pecking Order Theory

According to Wibowo (2007:26), Packing order theory is a sequence of funding sources from internal (retained earnings) and external new equity issuers. Managers know more about their own company's prospects than outside investors.

\section{Macroeconomics}

Macroeconomics or macroeconomic theory is a branch of economics that studies economic events in aggregate. It should be noted that every company will feel the impact of macroeconomic changes, the impact can be seen from the conditions of inflation, interest rates, exchange rates and economic growth.

Inflation : An economic event that often happens even though we never want it. Milthon Friedman said inflation is everywhere and is always a monetary phenomenon that reflects excessive and unstable monetary growth. The definition of inflation is a tendency to increase general prices continuously, Dwi Eko Waluyo, (2011; 117). Inflation is an event that shows an increase in the price level in general and takes place continuously.

Interest rate : Interest is a form of income/income for fund owners who have sacrificed their funds for some time giving up the opportunity not to use their funds because they are used by other parties. Interest is the value or price that must be paid by the borrower or user to obtain funds from the provider or user to obtain funds from the provider or owner of the funds for a mutually agreed period of time. Darmawi.H, $(2005 ; 133)$

Interest rate is one of the monetary indicators that has an influence on the economic growth of a country, the government as the manager of the national economy pays great attention to the development of interest rates along with other instruments. 1.) The interest rate will ensure that savings flow to investments that can increase economic growth. 2.) The interest rate will bring the money supply into balance with the people's money needs 3.) The interest rate can encourage the supply of credit to investment projects with the expectation of the highest profit 4.) The interest rate as a government instrument in using monetary policy to stimulate and encourage economic growth 5.) The interest rate will affect investment decisions which in turn affect the rate of economic growth. 6) The interest rate affects the choice of investment in the real or non-real sector. 7) Interest rates affect the business continuity of banks and other financial institutions. 8.) The interest rate will affect the volume or the amount of money in circulation.

\section{Financial Risk Management}

The emergence of unexpected events can result in losses. Investors who hold shares are worried about falling stock prices. The bank is worried that if the debtor declares a default, Nick Leeson from Baring bank, which carries out transactions with very large sizes, will suffer losses that make Baring Bank bankrupt. The sharp depreciation of the rupiah against the USD made many companies suffer huge losses. The potential for large losses caused by unwanted events is a measure of the risk faced by the company. Risk is loss due to unexpected events, T. Sunaryo (2009:11).

\section{Profitability performance}

Prafitability is one measurement for the performance of a company, the profitability of a company shows the ability of a company to generate profits during a certain period at a certain level of sales, assets and share capital. The profitability of a company can be assessed in various ways depending on the profits and assets or capital that will be compared with one another.

Return on equity or profitability is a measurement of the income or income available to company owners for the capital they invest in the company. Committee on terminology defines profitability as the amount derived from the reduction in the cost of production, other costs and losses from income or operating income. Meanwhile, according to Harahap (2004:226) statement defines profitability as excess income over costs during an accounting period. Profitability is the main measure of the overall success of the company Simanora (2006:528). From the above understanding it can be concluded that profitability is the income desired by the company in the activity of selling output or products during the accounting period.

\section{Value of The Firm}

According to Sartono (2012: 487), the value of the company is the selling value of a company as an operating business. The existence of an excess selling value over the liquidation value is the value of the management organization that runs the company. According to Harmono (2011: 233), the value of the company is the company's performance which 
is reflected by the stock price formed by the demand and supply of the capital market which reflects the public's assessment of the company's performance. According to Irham Fahmi $(2012,185)$, the value of the company is a condition that has been achieved by a company as an illustration of public trust in the company after going through a process of activities for several years, namely since the company was founded until now. According to Brigham and Erdhadt (2006: 118), firm value is the present value of free cash flow in the future at a discount rate according to the weighted average cost of capital. Free cash flow is cash flow available to investors (creditors and owners) after taking into account all expenses for company operations and expenses for investment and net current assets. According to Gitman (2012: 152), company value is the actual value per share that will be received if the company's assets are sold according to the share price.

\section{RESEARCH METHOD}

The researcher determines the type of quantitative research, because the research data is in the form of numbers and is analyzed using statistics. Descriptive data analysis technique, is a technique used to analyze data by describing or describing the data that has been collected, without any intention of making generalizations from the results of the study, Sugiono $(2017 ; 57)$. The data used by researchers is secondary data, the data in this study were obtained from the IDX website (Indonesia Stock Exchange).

The data that the researchers got from the source of the Indonesia Stock Exchange (IDX) http/www.idx.co.idx. The number of data on the Jakarta Islamic Index stock companies is 30 companies, based on research interests with the following criteria:

1. All companies listed on the Jakarta Islamic index, consistently in making annual reports, during the period 2013-2017.

2. The company has consistently published annual financial reports, during the 2013-2017 period.

3. Companies that provide data related to research variables, experienced successive profits during the researchers' observations and during the 2013-2017 period.

So that the population used in this study amounted to 16 companies. Jakarta Islamic Index, because all the population of 16 stock companies as the research sample, in this study it means that the sample is a saturated sample. Research data sources from the Capital market directory (ICMD) and Indonesia stock exchange (IDX), in the form of company financial statements. The performance of Indonesian companies and banks in the form of interest rates, exchange rate inflation and financial risk management.

\section{Conceptual Framework Drawing}

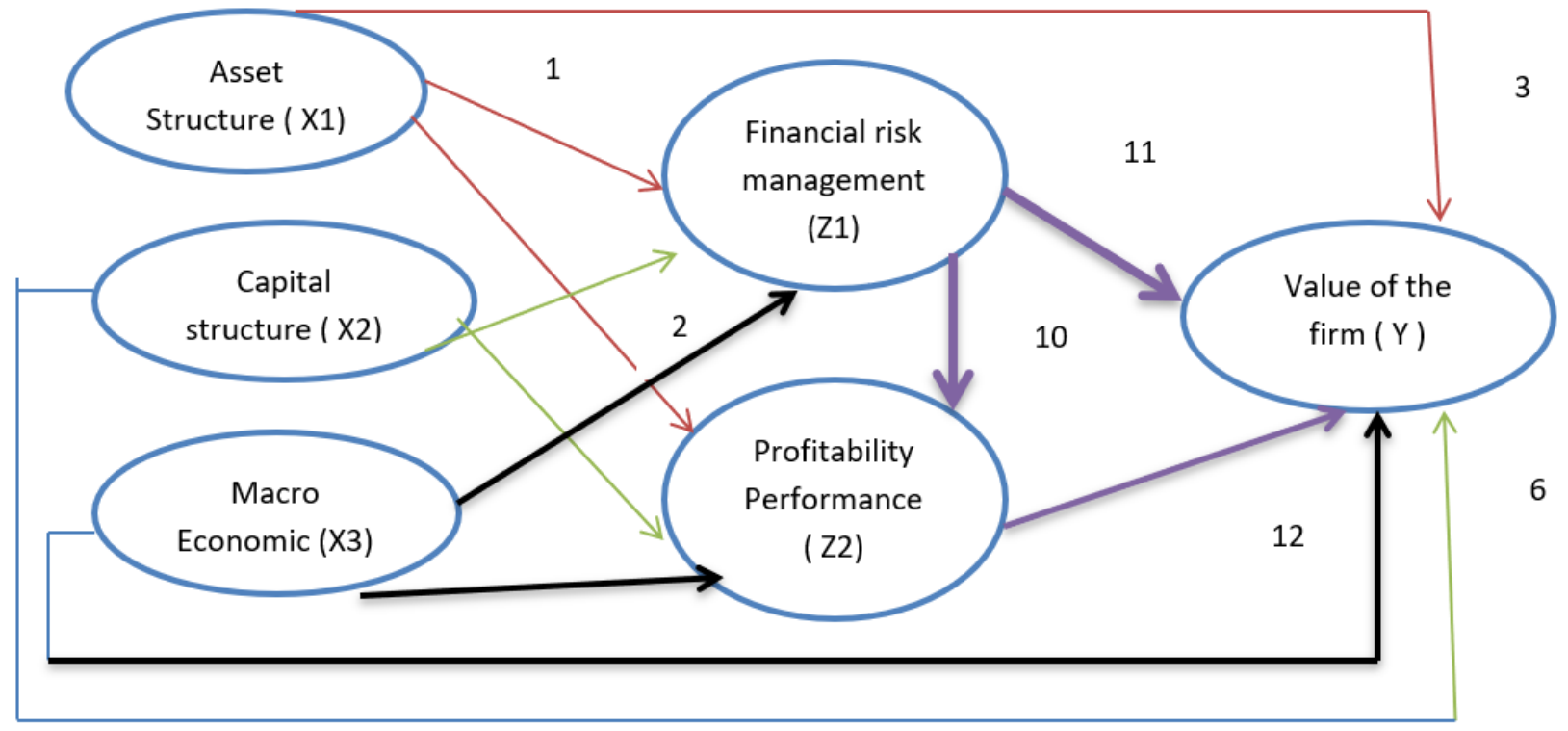

\section{Data Analysis Techniques}

This study uses quantitative data analysis techniques, namely using statistics, with PLS (Partial Least Square) analysis tools According to Imam Ghazali (2014: 6) Partial Least Square (PLS) is a powerful analytical method and is often referred to as soft modeling because it provides assumptions OLS (Ordinary Least Square) regression, such as data must be normally distributed in a multivariate manner and there is no multicollinearity problem between exogenous variables. The purpose of Partial Least Square (PLS) is to help researchers to get the value of the latent variable for prediction purposes. 
International Journal of Social Science (IJSS)

Vol.1 No.3 October 2021, pp: 265-274

ISSN: 2798-3463 (Printed) | 2798-4079 (Online)

\section{Model Evaluation}

Covergent validity of the measurement model with reflexive indicators is assessed based on the correlation between the item score / component score and the construct score calculated by PLS. Individual reflexive measure is said to be high if it has a correlation of more than 0.70 with the construct to be measured. However, for research in the early stages of developing a measurement scale, a loading value of 0.5 to 0.60 is considered sufficient (Ghozali, 2014:39).

The inner structural model (inner model) is carried out to examine the relationship between latent constructs in PLS and which describes the relationship between latent variables in the research model, starting by looking at the $\mathrm{R}$-square for each dependent latent variable, the higher the $\mathrm{R}$-square value, the greater the ability of the variable. This can explain the targeted variable. The influence between variables is considered significant at the 5\% level if the statistical $t$ value of the data results is greater than $t$ table. Test the hypothesis by looking at the estimate for path coefficients, which is the path coefficient value or the magnitude / effect of the latent construct.

Outer model, measurement of indicators on latent variables that test validity and test reliability. The reflective measure is said to be high if the loading factor is more than 0.7 with the construct to be measured, but if the value is above 0.5 or 0.6 for the intended construct it is acceptable. In addition to the loading factor on the convergent validity test, the value (AVE) can be seen, it is said to be valid if the value is above 0.5 .

\section{Research Results and Discussion}

Asset Structure

The asset structure has an important role in determining activities, namely company financing, where the asset structure also determines the amount of fund allocation for each component, both current assets and fixed assets.

\section{Capital Structure}

The capital structure combines permanent sources of funds used by the company in a way that is able to maximize the value of the company.

\section{Macroeconomics}

Macroeconomics has a considerable influence in every company's economic activities, which is always measured by inflation, namely the increase in overall prices. The exchange rate is known as the exchange rate of currency against current or future payments between two different countries.

\section{Financial Risk Management}

The purpose of financial risk mangament arises as a result of unexpected events. Risk is caused by, among others, currency, credit, commodity and equity values. In addition there are also other risks that can occur, namely regulatory risk, tax risk, liquidity risk and market risk.

\section{Profitability Performance}

Comparison to determine the company's ability to earn profit (profit), from revenue (earnings). Disclosure of the final results of all financial policies and operational decisions made by management within the company. Value of The Firm

It is an investor's perception of the company's level of success which is often associated with stock prices.

\section{RESULTS AND ANALYSIS}

\section{There is no significant influence of Asset Structure on Financial Risk Management at JII}

This study has an effect value of 1.051764 which is smaller than the T statistic of 1.96, which means that the effect is not significant. The research sample of the Jakarta Islamic Index, the greater the asset value does not affect the unexpected risk. This means that the company's asset structure plays an important role in determining the company's financing, where the company is to finance short-term and long-term liabilities. Furthermore, if the asset structure is not managed properly either result in a negative effect on financial risk management. Because the higher the risk of asset turnover, the faster the current assets obtained by the company

There is no significant influence of Asset Structure on Financial Risk Management because there are three companies (BSDE, SMRA, WIKA) that do not include the value of current assets, only include total assets, resulting in the value of current assets having no effect.

\section{There is a significant influence of Asset Structure on Profitability Performance at JII}

This study has an influence value of 17.051622, which is greater than the T statistic of 1.96, which means it has a significant effect. The sample of the Jakarta Islamic index research, the larger it affects the level of the company in seeking profit. This means that the company's ability to meet short-term obligations in generating profits is capitalized from Current assets and fixed assets have a positive effect, this shows that the company is able to meet short-term obligations, so it has an impact on increasing profits. The company's asset structure plays an important role in 
determining the financing of companies that have high long-term fixed assets because of the high demand for their products. due to using a lot of long-term debt.

\section{There is a significant influence of Asset Structure on the Value Of The Firm at JII}

This study has an effect value of 12.522477 which is greater than the T statistic of 1.96 , which means that it has a significant effect. The research sample of the Jakarta Islamic index, the greater the asset value, the greater the company's ability to increase profits. Asset structure has a significant effect on the Value Of The Firm. Comparative analysis between fixed assets and total assets and firm value. If the company is managed properly, it can be used as an assessment for the company's stakeholders.

\section{There is a significant effect of Capital Structure on Financial Risk Management at JII}

This study has an influence value of 6260.609622 which is greater than the T statistic of 1.96 , which means that it has a significant effect. The research sample of the Jakarta Islamic index, shows that a good capital structure is very influential on the risk of uncertainty. Analysis of financial measures between short term, long term and own capital in carrying out company activities, unexpected credit risk losses. If the company is managed properly, it can be used to provide potential risks associated with interest payments and principal repayments

\section{There is a significant effect of Capital Structure on Profitability Performance at JII}

This study has an influence value of 3.586426 which is greater than the T statistic of 1.96 , which means that it has a significant effect. The research sample of the Jakarta Islamic index, shows that a good capital structure greatly affects the company's performance in increasing maximum profit. Analysis of financial measures between short-term, longterm and own capital in carrying out company activities, measuring company performance, namely the company's ability to generate profits. If the company is managed properly, it can be used as a reference for planning.

\section{There is no significant effect of Capital Structure on Value Of The Firm at JII}

This research has an effect value of 0.430160 which is smaller than the T statistic of 1.96 , which means that it has no significant effect. The research sample of the Jakarta Islamic index, shows that a good capital structure does not affect the value of the company, this is because the company's capital uses more debt capital (third parties) with a higher interest rate. If the company manages its capital structure well, it has no effect on the value of the company. The analysis of financial measures between short-term, long-term and own capital in carrying out company activities does not affect the value of the company. This happens because the company's ability to meet long-term obligations does not fulfilled so that it affects the value of the company in increasing profit.

\section{There is a significant effect of Macroeconomics on Financial Risk Management at JII}

This study has an influence value of 5.463214 which is greater than the T statistic of 1.96 , which means that it has a significant effect. The research sample of the Jakarta Islamic index, shows that macroeconomics is very influential on the risk of unexpected losses. The company's overall analysis can be seen from inflation, interest rates and exchange rates, will affect the company's financial risk. Unexpected losses can be seen from credit risk and growth risk. If the company can manage the occurrence of macroeconomic events, it will affect the company's financial risk.

\section{There is a significant effect of Macroeconomics on profitability performance at JII}

This study has an influence value of 5.253573 which is greater than the T statistic of 1.96 , which means that it has a significant effect. The research sample of the Jakarta Islamic index shows that macroeconomics as measured by inflation, interest rates and exchange rates greatly affect the company's performance in maximizing profit. This means that inflation, interest rates and crucibles greatly affect profitability performance. If there is an increase in interest rates where the company borrows funds from the bank, it will affect the company's performance in generating profits. If there is inflation where the purchasing power of the people decreases, it will also affect the profitability performance in generating profits. Likewise with the exchange rate if the increase in the value of the currency will also affect the company's profitability performance, namely in increasing profits.

\section{There is a significant effect of Macroeconomics on the Value Of The Firm at JII}

This study has an effect value of 3.982465 which is greater than the T statistic of 1.96 , which means that it has a significant effect. The research sample of the Jakarta Islamic index, shows that the macro economy is influenced by the value of the company which is always related to interest rates, inflation and exchange rates in increasing the value of the company in the market. Macroeconomic variables consisting of inflation, interest rates and exchange rates have an impact on the value of the company, namely increasing the company's profit in the future.

10. There is a significant influence of Financial Risk Management on Profitability Performance at JII

This study has an influence value of 3.564893 , which is greater than the T statistic of 1.96 , which means that it has a significant effect. The research sample of the Jakarta Islamic index, shows that there must be uncertainty in running a company, which is often referred to as economic uncertainty, of course, it greatly affects the company's prospects in the future in increasing market confidence. The company's financial risks if managed properly and correctly will bring profits to the company. In this case, the condition of the Islamic capital market is influenced by 
International Journal of Social Science (IJSS)

Vol.1 No.3 October 2021, pp: 265-274

ISSN: 2798-3463 (Printed) | 2798-4079 (Online)

macroeconomic factors, namely inflation which has an impact on the decline in people's purchasing power for company shares. Interest rates have an impact on the rise and fall of interest rates on company loans at banks.

\section{There is a significant influence of Financial Risk Management on Value Of The Firm at JII}

This study has an effect value of 1.952247 which is smaller than the T statistic of 1.96 , which means that it has a significant effect. The research sample of the Jakarta Islamic index, shows that unexpected losses by the company greatly affect the value of the company, where the company's goal is to increase the maximum profit. If the company is able to manage financial risk, it will affect the value of the company, namely in increasing profits. Credit risk analysis, corporate risk affects the value of the company in measuring how much the company's ability to increase profits.

\section{There is a significant effect of profitability performance on the value of the firm at JII}

This study has an influence value of 5.543722 which is greater than the T statistic of 1.96 , which means that it has a significant effect. The research sample of the Jakarta Islamic index, shows that profitability performance is used to review the company's ability to generate profits (profit). In fact, profitability performance is an achievement achieved by the company in managing the company's assets to evaluate the level of success of the company based on the financial activities that have been carried out, if done properly will have an impact on the value of the company, namely in increasing profits

\section{CONCLUSION}

1. Risky assets rarely provide the expected rate of return. In general, risky assets provide higher or lower than expected returns. If the asset always produces the expected return, then the asset is not at risk.

2. These results indicate that the company's ability to meet short-term obligations in generating profits capitalized from current assets and fixed assets has a positive effect, this shows that the company is able to meet short-term obligations, which has an impact on increasing profits. The company's asset structure plays an important role in determine the financing of companies that have high long-term fixed assets because of the high demand for their products because they use a lot of long-term debt.

3. These results indicate that the asset structure is a comparative analysis between fixed assets and total assets and firm value. If the company is managed properly, it can be used as a company's success which is closely related to its share price.

4. Analysis of financial measures between short term, long term and own capital in carrying out company activities, unexpected credit risk losses. If the company is managed properly, it can be used to provide potential risks associated with interest payments and principal repayments. To achieve the company's goal of maximizing shareholder wealth, financial managers can assess the capital structure and understand its relationship to risk, return or value return.

5. The capital structure can change due to the company's policies taken related to funding, in the form of short-term debt, long-term debt. Capital structure is a measurement of company performance, namely the company's ability to generate profits. If the company is managed properly, the company will be able to fulfill its obligations and increase the company's profitability.

6. Capital structure is the company's ability to meet obligations, if the company manages its capital structure well, it will have an impact on increasing the value of the company, on the contrary if the company is not managed properly it will affect the value of the company.

7. These results show that the overall incidence of the company can be seen from inflation, interest rates and exchange rates, will affect the company's financial risk. Unexpected losses can be seen from credit risk and growth risk. If the company can manage the occurrence of macroeconomic events, it will affect the company's financial risk.

8. If there is inflation where the purchasing power of the community decreases, it will also affect the profitability performance in generating profit. Likewise with the exchange rate if the increase in the value of the currency will also affect the company's profitability performance, namely in increasing profits.

9. In a business, macroeconomics plays a role in influencing policies such as price stability, economic growth, employment and achieving balance. Macroeconomics consists of several components that can directly influence the decision making of a company, including the development of the company. Macroeconomic problems in business are poverty and unemployment, exchange rate crises against foreign debt, banking problems and bad loans, economic growth.

10. The company's financial risks if managed properly and correctly will bring profits to the company. More risk leads to a failure that is not expected and usually occurs in the daily activities of the company. 
11. If the company is able to manage financial risk, it will affect the value of the company, namely in increasing profits. Analysis of credit risk, corporate risk affects the value of the company in measuring how much the company's ability to increase profits. Basically, risk always exists in everyday life.

12. In fact, profitability performance is an achievement achieved by companies in managing company assets to evaluate the company's success rate based on financial activities that have been carried out, if done properly will have an impact on company value, namely in increasing profits. Profitability ratios are often used to determine the company's ability to generate profits. profit.

\section{Suggestions}

1. In deciding to invest, investors should consider asset structure, capital structure, macroeconomics, financial risk management, profitability performance, going concern and GCG. Companies that have high disclosure of the above variables indicate that the company has good implementation in managing the company.

2. Companies listed on the Jakarta Islamic Index must maintain the asset structure, capital structure and profitability performance contained in the published financial statements. And must apply the principles of GCG in order to achieve good corporate governance, then also must be a going concern in order to maintain the life of the company in the future

\section{REFERENCES}

[1] Aditya, Oka, dan Prima Naomi, 2017, Penerapan Menajemen Resiko Perusahaan Dan Nilai Perusahaan Disektor Konstruksi Dan Property, halaman 2461 - 1182rn, Jurnal Bisnis dan Manajemen, vol.7 (2) Oktober 2017

[2] Attar, Dini, dan Islahuddin dan M.Shbabri, 2014, Pengaruh Penerapan Manajemen Resiko Terhadap Kinerja Keuangan Perbankan yang terdaftar di BEI, halaman 10 - 20.Jurnal Akuntansi, vol.3, no.1, Februari 2014, pages pp,10-20, Universitas Syiah Kuala

[3] Bisnis.com, Jakarta, Emanuel B. Caesario | 19 Maret 2019 10:30 WIB)

[4] Boediono, 2014, Ekonomi Makro, Penerbit: BPFE Yogyakarta

[5] Dhani, Isabella Permata, dan A.A.Gede Setia Utama, 2017, Pengaruh Pertumbuhan, Struktur Modal Dan Profitabilitas Terhadap Nilai Perusahaan. Halaman 135 - 148, Jurnal Riset Akuntasi dan Bisnis Airlangga, Vol 2 no 1,2017

[6] Djorwanto, 2004, Pokok-Poko Analisis Laporan Keuangan, Edisi 1, penerbit: BPFE, Yogyakarta.

[7] Dwipartha, Ni Made With a, 2013, Pengaruh Faktor-Faktor Ekonomi Makro Dan Kinerja Keuangan Terhadap Nilai Perusahaan Manufaktur, BEI, halaman 226 -248. Jurnal Ekonomi dan Bisnis, Fakultas Ekonomi, Universitas Udayana,

[8] Eardhana, Jaya Iga Bagus dan Wisnu Mawardi, 2016, Analisis Pengaruh Struktur Aktiva, Asset Turnover, Growth Terhadap Profitability Melalui Variabel Capital Structure Sebagai Variabel Intervening (Studi Kasus pada Perusahaan Consumer Goods BEI Periode Tahun 2012-2014)

[9] Fahmi, Irham, 2012, Analisis Laporan Keuangan, cetakan ke 2, penerbit: Alfabeta, Bandung

[10]Faisal, Muhammad, 2016, Pengaruh Nilai Tukar Rupiah (kurs), Inflasi Dan Pertumbuhan Ekonomi Terhadap Retrun Saham Pada Perusahaan Perbankan Yang BEI, halaman 232 - 250, Jurnal Valuta, vol.2, no.2, Oktober 2016

[11]Farida, Mawar, dan Ari Darmawan, 2017, Pengaruh Resiko Inflasi, Resiko Suku Bunga, Resiko Valuta Asing Dan Profitabilitas Retrun Saham.halaman 49 - 57. Jurnal Administrasi Bisnis (JAB) vol.50, no.1 Oktober 2017

[12] Fred, J, Weston dan E.F.Brigham, 2005, Dasar-Dasar Manajemen Keuangan, edisi 9, penerbit: Erlangga, Jakarta.

[13] Ghozali, Imam, 2014, Structural Equation Modeling, PLS, penerbit: Universitas Diponegoro, Semarang

[14] Hapsari, Ajeng Andrianai, 2017, Pengaruh Tata Kelola Perusahaan Terhadap Manajemen Resiko Pada Perbankan Indonesia, halaman 1-10,Jurnal Muara Ilmu Ekonomi dan Bisnis, vol.1, no.2 Oktober 2017

[15] Harahap, Sofyan Syafri, 2004, Analisis Kritis Atas Laporan Keuangan, Penerbit: PT.Raja Grafindo Persada, Jakarta

[16] Harmono, 2011, Manajemen Berbasis Balance Scorecard pendekatan Teori, Kasus dan Riset, penerbit: Bumi Aksara, Jakarta

[17] Hwihanus, 2019, Antecedents Value Of The Firm, penerbit LPPM Universitas 17 Agustus 1945, Surabaya

[18] Sugiyono, 2017, Metode Penelitian, Kuantitatif, Kualitatif, dan R\&D, penerbit:Alfabeta, Bandung.

[19] Supriyono, 2002, Akuntansi Biaya, cetakan 3, penerbit: BPFE, Yogyakarta.

[20] Sutrisno, 2012, Manajemen Keuangan Teori, Konsep dan Aplikasi, Penerbit: Ekonisia, Yogyakarta

[21] Syamsudin, Lukman 2007, Manajemen Keuangan Perusahaan, cetakan 5, penerbit: PT.raja Grafindo Persada, Jakarta.

[22] Waluyo, Dwi Eko, 2011, Teori Makro Ekonomi, cetakan keempat, penerbit: Universitas Muhammadiyah, Malang 
International Journal of Social Science (IJSS)

Vol.1 No.3 October 2021, pp: 265-274

ISSN: 2798-3463 (Printed) | 2798-4079 (Online)

[23] Wijaya, Sucita, I Putu Andre, dan I Made Karya Utama, 2014, Pengaruh Profitabilitas, Struktur Asset dan Pertumbuhan Penjualan terhadap Struktur Modal Serta Harga Saham. Halaman 514 -530, Jurnal Akuntasi Universitas Udayana 6.3(2014):514-530

[24]Zaki, Baridwan, 2004, Intermediate Accounting, Edisi delapan, penerbit: Yogyakarta:BP 
